Board of Governors of the Federal Reserve System

\author{
International Finance Discussion Papers
}

Number 535

January 1996

\title{
THE RISKS AND IMPLICATIONS OF EXTERNAL FINANCIAL SHOCKS: LESSONS FROM MEXICO
}

\author{
Edwin M. Truman
}

NOTE: International Finance Discussion Papers are preliminary materials circulated to stimulate discussion and critical comment. References in publications to International Finance Discussion Papers (other than an acknowledgment that the writer has had access to unpublished material) should be cleared with the author or authors. 


\section{ABSTRACT}

The lessons from the 1994-95 Mexican peso crisis are examined from the perspective of creditors and their markets, countries that are recipients of large capital inflows, and the functioning of the international system as a whole. From each of these perspectives, recent changes in the financial world are sketched, lessons from the Mexican experience are derived, and implications for policies are considered. 
The Risks and Implications of External Financial Shocks: Lessons from Mexico

Edwin M. Truman ${ }^{1}$

\section{Introduction}

In this paper, I focus on the risks and implications of external financial shocks in the context of the lessons to be learned from the Mexican experience from three perspectives: the creditors and their markets, the countries that are recipients of large capital inflows, and the functioning of the international financial system as a whole. With respect to each of these perspectives, I consider how the financial world has changed in recent years, the lessons from the Mexican experience, and the implications, in particular for policies, that should be drawn or at least examined.

This three-by-three classification system is somewhat arbitrary and, therefore, not entirely satisfactory. First, to the extent that creditors are identified with investors in industrial countries, recipients of capital inflows (net or gross) are identified with developing countries, and the system is identified with the governments (and the central banks) of

1. The author is Staff Director, Division of International Finance, Board of Governors of the Federal Reserve System. An earlier version of this paper was prepared for and presented to the Aspen Institute Seminar "The Future of the World Economy," August, 1995. I benefitted from comments and assistance from my colleagues Tom Connors, Allen Frankel, David Howard, Catherine Mann, Larry Promisel, Margarita Serafini, Charles Siegman, Lois stekler, Betsey Stevenson, and Henry Terrell. Of course, none of them should be held to be responsible for any errors of fact or interpretation. This paper represents the views of the aut or and should not be interpreted as reflecting the views of the Board of Governors of the Federal Reserve System or other members of its staff. 
creditor countries and with the international financial institutions that are held responsible for its smooth operation, my classification is oversimplified. In today's liberalized financial markets, potential creditors include investors in developing countries, industrial countries are large scale recipients of international capital flows, and the authorities in developing countries as well as in industrial countries have a stake in the efficient and effective functioning of the international financial system. Thus, the notion that it is either appropriate or desirable for developed countries to operate under one set of rules while developing countries operate under another set of rules is increasingly off the mark.

Second, the origins of the 1995 Mexican crisis can be traced, in part, I believe, to trends in the globalization of finance over the past decade, trends with respect to the technology of markets, the liberalization of financial systems, and diversification of investors' portfolios. Whether these factors contributed importantly to what happened in Mexico in late 1994 and early 1995 or whether Mexican economic policy decisions were more decisive does not need to be agreed for the sake of my argument. I would merely stipulate that there is more in common between the behavior of financial markets during the Mexican crisis and their behavior during the ERM crises of 1992 and 1993 and the bond market collapse in 1994 than many observers 
may be willing to contemplate or acknowledge. ${ }^{2}$ Moreover, the similarities between the economic policies contributing to the Mexican crisis and the ERM crises attest to the fact that the former was not a unique or unidimensional event. 3

As a final qualification, I would note that establishing the lessons to be learned from the Mexican experience is complex. There is no consensus on the factors behind the crisis. The International Monetary Fund lists three major views -- adverse domestic political and external economic shocks, an unsustainable external position, and domestic policy slippages -- and notes that these views are not mutually exclusive. 4 Moreover, the IMF's list of explanations largely omits economic and financial trends and developments originating outside of Mexico. In part because there is no consensus on the factors behind the Mexican crisis, there is no consensus about what should have been done or not done during the crisis. Therefore, the lessons one person draws from the crisis are likely to be quite different from another person's lessons.

2. Alan Greenspan testified before Congress on January 26, 1995, "although the speed of transmission of positive economic events has been an important plus for the world in recent years, it is becoming increasingly obvious - - and Mexico is the first major case -- that significant mistakes in macroeconomic policy also reverberate around the world at a prodigious pace." Federal Reserve Bulletin, March 1995, page 261.

3. These parallels are much too interesting, complex or controversial to be explored extensively in this paper, but they are there and important to our understanding of today's Einancial world.

4. International Monetary Fund, World Economic Outlook, May 1995, pp. 90-97. 
I. The Creditors and Their Markets

A. Recent Trends and Developments

Table 1 below provides a summary overview of capital flows to developing countries since the early 1970s. A number of points can be illustrated by the data presented in the table.

First, note the absence of lines for official capital inflows. Such flows are buried in the "other" lines and their importance in capital inflows to developing countries in Asia and the Western Hemisphere has declined substantially in recent years. Considering total net capital inflows to all developing countries, borrowing from official creditors declined from $\$ 20$ billion per year from 1987 to 1990 (60 percent of total net flows) to $\$ 16$ billion per year from 1991 to 1994 (11 percent of total net flows). 5

Second, net flows directly involving foreign commercial banks are also included in the "other" lines. This was the principal source of capital inflows from 1973 to 1982 for developing countries in Asia and the Western Hemisphere. During the debt-crisis period of the 1980s, countries in the latter group experienced a reversal of such flows, and bank flows played

5. These data are compiled on a different basis from those presented in Table 1 and intra alia include "exceptional financing" some of which comes importantly from the official sector even for the more advanced developing countries. The comparable figures for developing countries in the Western Hemisphere are net borrowing from official creditors of $\$ 7.9$ billion per year from 1987 to 1990 and net repayments of $\$ 0.7$ billion per year from 1991 to 1994. Finally, for 22 countries classified by the IMF as market borrowers, net inflows from of official creditors were $\$ 2.6$ billion per year from 1987 to 1030 ( 14 percent of the total) and $\$ 3.2$ billion per year from $15 y 1$ to 1994 (3.6 percent of total). Source: IMF, World Economic Outlook, May 1995, Tables A33, A34 and A35. 
Table 1

Capital Flows to Developing Countries, 1973-94 $1 /$

(Annual Averages; in billions of U.S. dollars)

$1973-76 \quad \underline{1977-82} \quad \underline{1983-89} \quad \underline{1990-94}$

All developing countries 2/

Total net capital inflows

Foreign direct investment

plus portfolio investment (net)

Net foreign direct investment

Net portfolio investment

other $\underline{3}$ /

Asia

Total net capital inflows

Foreign direct investment

plus portfolio investment (net)

Net foreign direct investment

Net portfolio investment

other $\underline{3} /$

Western Hemisphere

Total net capital inflows

Foreign direct investment

plus portfolio investment (net)

Net foreign direct investment

Net portfolio investment

other $\underline{3} /$

other developing countries $2 /$

Total net capital inflows

Foreign direct investment

plus portfolio investment (net)

Net foreign direct investment

Net portfolio investment

other $3 /$

$\begin{array}{cccc}14.8 & \underline{30.5} & \underline{8.8} & \underline{104.8} \\ -1.8 & 0.7 & 19.8 & 82.7 \\ (3.7) & (11.2) & (13.3) & (39.1) \\ (-5.5) & (-10.5) & (6.5) & (43.6) \\ 16.6 & 29.8 & -11.0 & 22.2\end{array}$

$\begin{array}{cccc}6.7 & 15.8 & 16.7 & 52.2 \\ 1.4 & 3.3 & 6.6 & 35.8 \\ (1.3) & (2.7) & (5.2) & (23.4) \\ (0.1) & (0.6) & (1.4) & (12.4) \\ 5.3 & 12.5 & 10.1 & 16.3\end{array}$

$13.0 \quad 26.3 \quad-16.6 \quad 40.0$

$\begin{array}{llll}2.4 & 6.9 & 3.2 & 38.5\end{array}$

$\begin{array}{llll}(2.2) & (5.3) & (4.4) & (11.9)\end{array}$

$\begin{array}{llll}(0.2) & (1.6) \quad(-1.2) & (26.6)\end{array}$

$\begin{array}{llll}10.6 & 19.4 & -19.8 & 1.5\end{array}$

$\begin{array}{cccc}-4.9 & -11.6 & 8.7 & 12.7 \\ -5.6 & -9.5 & 10.0 & 8.3 \\ (0.2) & (3.2) & (3.7) & (3.8) \\ (-5.8) & (-12.7) & (6.3) & (4.6) \\ 0.7 & -2.1 & -1.3 & 4.3\end{array}$

Memorandum Items :

Mexico

Total net capital inflows

Foreign direct investment

plus portfolio investment (net)

Net foreign direct investment

Net portfolio investment

other $\underline{3} /$

$\begin{array}{cccc}\text { n.a. } & 9.7 & -2.1 & 21.2 \\ \text { n.a. } & 2.3 & 0.1 & 18.7 \\ \text { (n.a.) } & (1.6) & (1.2) & (4.9) \\ \text { (n.a.) } & (0.7) & (-1.1) & (13.8) \\ \text { n.a. } & 7.4 & -2.2 & 2.5\end{array}$

Source: International Monetary Fund. World Economic Outlook database.

I/ Flows exclude exceptional financing (from IMF or IBRD, and bilateral

official or private sector reschedulings or arrears). A number of countries

do not report assets and liabilities separately. For these countries, it is

assumed that there are no outflows, so that liabilities are set equal to the net value. To the extent that this assumption is not valid, the data underestimate the gross value. Adjustments are also made to the WEO data to net out the effects of bonds exchanged for commercial bank loans in debt and debt service reduction operations and to provide additional detail on selected private capital flows.

2/ Excludes capital exporting countries such as Kuwait and Saudi Arabia.

$\underline{3}$ / Consists of net lending to the official sector (including general government and the monetary authority) and net lending to the private sector by banks and non-banks such as insurance companies and pension funds. 
only a moderate role during the first half of the 1990s. These data, however, do not reveal the extent of the involvement of commercial and investment banks in intermediating international capital flows because they include as banking flows only assets that end up on the balance sheets of those financial institutions; however, these institutions are heavily involved in the placement and arrangement of portfolio capital flows. For example, when the peso crisis erupted for Mexico in December 1994, Mexican commercial banks had about $\$ 4$ billion in certificates of deposit outstanding to nonresidents; an overwhelming proportion of those deposits had been placed or brokered by foreign financial institutions.

Third, the absolute and relative importance of net foreign direct investment has increased substantially. This trend reflects a widespread belief that this type of capital inflow has advantages in terms of relative stability and the countercyclical nature of the associated servicing requirements, and consequently a more hospitable attitude in recipient countries toward such inflows has developed over the past decade or so.

Fourth, the increase in net portfolio investment has been particularly dramatic. These flows take many forms, including investments in equity markets as well as investments in marketable debt instruments -- denominated in domestic as well as foreign currencies. In considering the implications of the recent Mexican experience, it is important to distinguish among these subcategories of portfolio investments because the 
investments involve a variety of different risks--price risk, liquidity risk, and exchange rate risk. Broadly speaking the investors behind those flows are of two types: direct holders of the instruments in question or indirect holders through investment trusts or mutual funds. Whatever the type of investor, they are seeking to maximize their return given their appetite for risk. Unlike many direct investors, portfolio investors often have relatively short time horizons regardless of the maturity of the underlying instruments. Unlike direct investors and traditional commercial bank lenders, they assume that they can liquidate their investments relatively quickly in well-developed trading markets. Moreover, relative near-term rates of return are important for some instruments, as may be considerations of capital gains and losses.

Fifth, in considering patterns of net capital flows to developing countries, not all countries or groups of countries are the same. The Asian countries all along have received a larger proportion of their net inflows through foreign direct investment. The Western Hemisphere countries experienced a reversal of inflows from banks in the 1980s, embedded in the "other" line, and they were relatively large beneficiaries of net portfolio inflows during the first half of the 1990s.

Finally, the pattern of net flows to Mexico shown in the memorandum items has been broadly the same as that shown for the 
Western Hemisphere countries as a group. 6

\section{B. Lessons from the Mexican Experience}

The lessons that observers draw from the Mexican

experience for the creditors and their markets depend importantly on the perceived uniqueness of the Mexican circumstances. 7 As we have seen, portfolio capital flows were important for Mexico, but its situation was similar to other countries in Latin America. It is true in the Mexican case that the portfolio inflows were concentrated in instruments with relatively short maturities that were also readily transferable. It is also true that by the time the crisis hit a large proportion of those instruments were Tesobonos whose peso value was linked to the value of the dollar. At the end of 1993, foreigners also were very large holders of Cetes -- short-term government securities whose value was not linked to the dollar. Indeed, one of the curiosities of the Mexican experience was that over the course of 1994 international (Mexican as well as foreign) investors as a group got out of Cetes but they willingly got into Tesobonos, instruments paying a much lower interest rate than Cetes but a higher rate than similar U.S. Government obligations. This trend continued even during the period after the middle of 1994 when it became clear that the outstanding stock of Tesobonos was larger than Mexico's foreign exchange holdings. By definition, the

6. In the period 1990-94, net portfolio investment was about two-thirds of net capital inflows to Mexico and the developing countries of the Western Hemisphere compared with just under a quarter for developing countries in Asia.

7. The same qualification applies to the lessons for the recipients of capital inflows (Section II) and for the international financial system (Section III). 
return associated with Cetes involved both an exchange rate and a credit (transfer) risk, while the return associated with Tesobonos involved principally the latter, but both were substantial. "A third "fact" about the Mexican situation may help to explain the relatively large ex ante gap between the rate on Cetes and that on Tesobonos: the international financial community led by the U.S. authorities had come to the financial assistance of Mexico on numerous occasions over the period dating back to 1976. The size and novelty of these operations may have suggested to investors that Mexico was different if not unique. Alternatively, investors did not fully appreciate that Tesobonos were a potential indirect claim on Mexico's international reserves.

Nevertheless, when the crisis broke, the objective situation was one in which a large number of geographically dispersed investors were caught holding short-term claims on Mexico that could not be serviced without incurring a massive short-run depreciation of the peso. They realized that their investment strategies had been based on one or more false premises concerning the nature of Mexico's exchange rate regime or the probability that they could liquidate their holdings before any crisis hit. While it is difficult to prove, a third

8. For example, at the end of November, 1994, the 91-day Cetes rate was 15.60 percent, a spread of 988 basis points over the U.S. 3-month Treasury bill rate of 5.72 percent, while the 91 -day Tesobono rate was 7.49 for a spread of only 177 basis points. Technically, there was some exchange rate risk originally associated with Tesobonos because their principal was only indexed to the dollar, but it was paid in pesos and the holder had to handle or cover the conversion of the pesos received into dollars. 
premise may have been that in the case of a crisis "bondholders" would not be affected because even during the severe debt crises of the 1980s there were only isolated instances of failures by countries to meet the original terms of this type of obligation. Finally, it is possible that investors had excessively bought into the so-called "Washington consensus" that the policy regimes in Mexico and similar countries had fundamentally changed in a direction that would produce sustained, rapid economic expansion. 9

In the event, in 1994-95 holders of some types of portfolio claims on Mexico suffered losses and holders of other types did not. Holders of equity securities suffered losses, or at least paper losses; the Mexican stock market dropped by twothirds (68 percent) in dollar terms between December 19, 1994 and its low on March 9, 1995, and as of the end of June was still about 45 percent below its level prior to the peso devaluation. The remaining foreign holders of cetes as well as domestic holders of those instruments suffered losses as well when their instruments matured over the course of 1995. Holders of the Tesobonos have not in the end suffered losses; the Mexican government has been able to honor its obligations, initially paying out pesos and meeting the resulting demand for dollars out of its reserves and later paying off foreign holders of Tesobonos directly in dollars. However, on a marked-to-market basis, holders of Tesobonos suffered non-trivial, but temporary, paper

9. See Paul Krugman, "Dutch Tulips and Emerging Markets," Foreign Affairs, vol. 74, number 4, July/August 1995, pp.28-44. 
losses as well, as did holders on other longer-dated Mexican debt instruments such as Brady bonds. Nevertheless, the widespread perception is that portfolio investors in Mexican paper suffered no losses as a consequence of the peso crisis and on the whole were well-rewarded for the limited risks they had taken.

When the crisis erupted, investors panicked, not only investors in the Mexican stock market and in Mexico debt instruments but also investors in similar instruments issued by borrowers in other countries, especially countries in the same part of the world or perceived to be in similar circumstances. These contagion sales of assets were induced by at least two types of forces. First, as perceived risks rose and expected returns fell, individual investors were induced to disinvest. Second, institutional holders such as mutual funds faced with actual or threatened redemptions were led to liquify their holdings not only of Mexican paper but also of the paper of other countries especially if they could do so while limiting their capital losses. These patterns can be seen in the sympathetic movements in the stripped yields on Brady bonds of various countries in Latin America and elsewhere -- see Charts 1 and 2. Whether they deserved it or not, the wealth of Mexico's external creditors as a group was only marginally affected by losses following the crash of the peso. The principal reason was that the investors were numerous and Mexican paper was not a large portion of any final, non-Mexican investor's total portfolio; a secondary reason was that some of the investors benefitted from the actions taken to stave off a larger crisıs. 


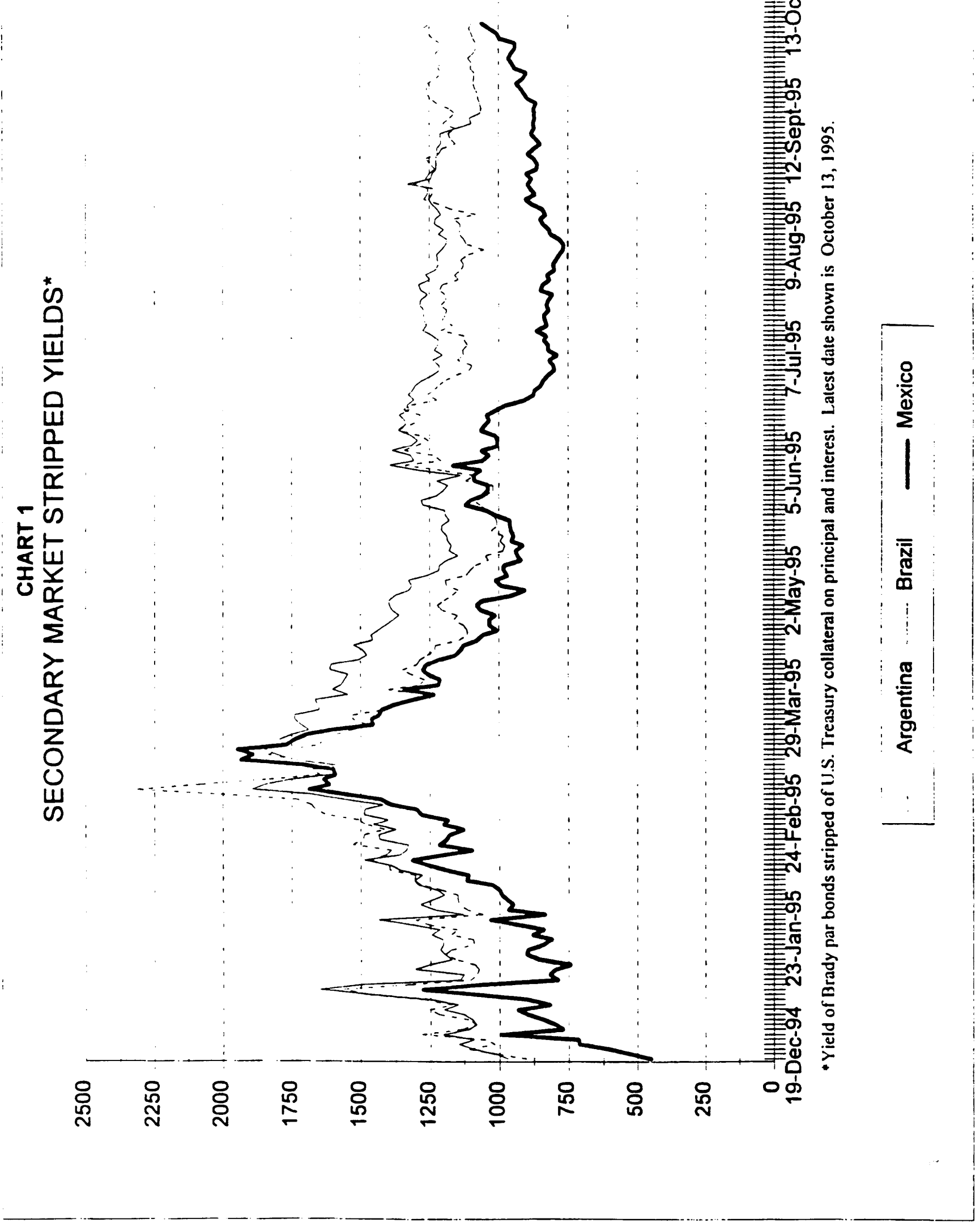




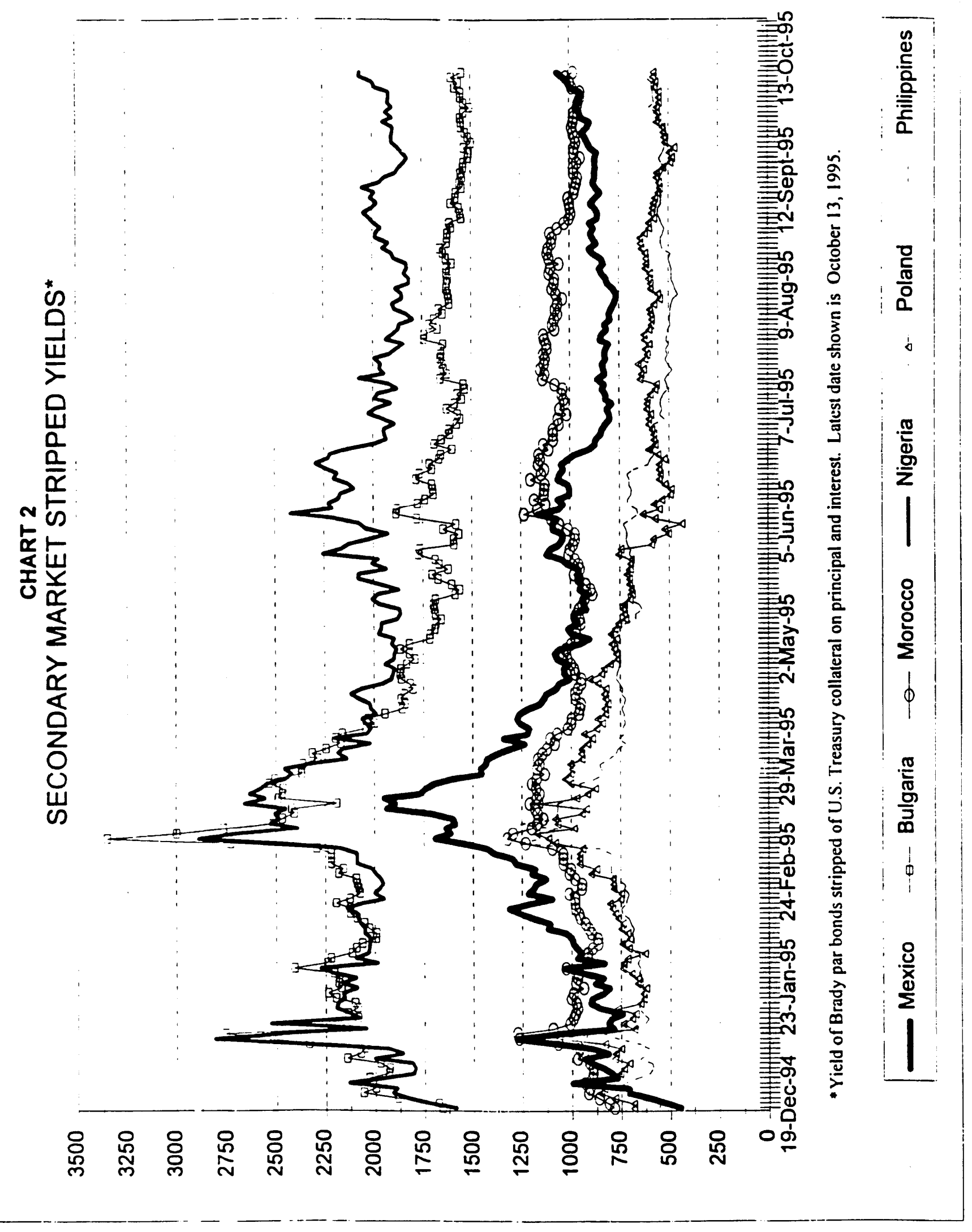


However, I would submit that the Mexican situation was not unique. As long as no major institution or group of institutions is heavily invested in claims on such a country or a group of similarly situated countries, creditors and their markets are likely to suffer limited damage. Consequently, they are unlikely to be motivated to act in concert to limit these losses on their investments; they have every incentive to step back from their investments and to seek to dispose of them quickly thereby adding to pressures in financial markets. On a global basis, portfolio investments in developing countries amounted to about $\$ 250$ billion as of the end of 1994 (see table 1). This is a large number, but it represents less than $1 / 2$ of one percent of total portfolio holdings of investors in industrial countries. 10 While they would not have been happy loosing, say, half the value of their investments in developing countries, the direct aggregate consequences in terms of lost wealth, welfare and demand were likely to be inconsequential. 11

One fact is clear in Mexico's case and applies with roughly equal force to many other countries: In contrast with the situation in the debt crisis of the early 1980 s when a small

10. As of 1992, the total GDP of high-income countries was three times U.S. GDP (Source: IBRD, World Development Report, 1994) and as of the end of 1994 U.S. households' financial wealth equalled $\$ 18$ trillion (Source: U.S. Flow of funds accounts); if the wealth/GDP ratio for all high-income countries is the same as the U.S. ratio, financial wealth of households in high-income countries equalied about $\$ 54$ trillion when the peso crisis broke out.

11. However, it is possible that in the future portfolio investments in these markets may become a larger share in clnbal portfolios. Moreover, the indirect consequences for globa: growth of the hypothesized loss in value in early $1995 \mathrm{might}$ have been substantial. 
number of international commercial banks -- roughly 25 in total -held a very dominant share of Mexico's debt, in 1994-95 that was not the case. In 1982 commercial banks accounted for 70 percent of Mexico's external debt, and claims on Mexico by the top nine U.S. commercial banks amounted to 50 percent of their capital. In contrast, at the end of 1994, less than 40 percent of Mexico's international debt was held by foreign commercial banks, and had Mexico defaulted, the consequences for those institutions would have been painful but not life threatening. In the case of the same group of major U.S. banks, claims on Mexico at the end of 1994 represented only 15 percent of their capital.

\section{Implications}

The Mexican peso crisis of $1994-95$ is likely to be unique in at least one respect: in future liquidity crises, holders of large amounts of portfolio claims on the country facing the crisis are much less likely to be made whole as the consequence of official actions that provide financial assistance to the country in question. 12 However, the fundamental point is that the scale of potential financial assistance needed to stave off a full-blown crisis in Mexico has proved to be much larger than anyone could have imagined a year ago, and the scale of any similar operation in the future (even after allowance for the special circumstances surrounding the Mexican casel is likely to be larger than the official sector will be able or willing to assemble. Moreover, like it or not, true or false, as noted

12. This implication is related, in part, to the discussion in section III below. 
above, the widespread perception is that many portfolio investors were inappropriately protected from the consequences of their investment decisions.

A further implication of the Mexican experience is that investors will be, or at least should be, more careful in the future. At a minimum, they should fine-tune their early-warning systems. Many of them reportedly did not understand developments in Mexico in 1993-94; if they had, they would not have invested so heavily in Tesobonos.

On the other hand, many of the investors or at least their advisors, in fact, did understand what was going on in Mexico in 1994, and those developments either were ignored by the managers of the investments or they believed that they could get out before a full-blown crisis erupted. Just as in the ERM crises of 1992 and 1993, many investors were mistaken. Thus, a third implication of the Mexican peso crisis is that institutions should pay more attention to their risk management systems in the broadest sense of that term. High or higher yields on debt instruments should serve as signals to their holders that compensation is being paid in advance for the costs of a possible default or capital loss.

Holders of portfolio claims on developing countries, as well as the financial institutions that are involved in placing the instruments whether or not they continue to hold any in their own portfolios, should plan on the basis that the next sovereign liquidity crisis will not unfold in the same way as the Mexican 
crisis unfolded. ${ }^{13}$ Their planning should have two dimensions:

They should expect to take more extensive losses. In part to improve the risk-reward trade off, they may want to consider how they might participate responsibly in the ex post resolution of crisis situations.

\section{The Recipients of Capital Inflows}

A. Recent Trends and Developments

The changing pattern of international capital flows has both a supply side and a demand side. Above we considered primarily the demand for a different mixture of investments than had been characteristic of the 1970s or 1980s, but the supply side is also important. From the standpoint of the recipient countries, the 1990 s opened up new opportunities to attract foreign capital.

In part those new opportunities were the consequence of changes in the governing political and social philosophies and economic policies of the recipient countries. ${ }^{14}$ They became more hospitable to foreign direct investment by relaxing restrictions, rewriting discriminatory regulations, and reworking the landscape of the public sector through massive privatization programs that, in turn, meant that portfolio investments in equity securities became more attractive. These forces of economic reform led to more flexible economies, economies that in principle were better

13. Again, this implication draws in part on the discussion in Section III below.

14. As noted above, some have argued that this so-called "Washington consensus" on policies may have been overblown $O_{\perp}$ overinterpreted in terms of its short-term implications for growth. 
equipped to respond to shocks. However, they involved two-way risks, at least potentially, because the recipient countries to some extent became more exposed to the risk of a sharp change in investor sentiment. Funds that flowed in and easily financed current account deficits could also easily seek to flow out if conditions or perceptions changed.

This proposition about the increased risk to the recipient country is debatable, and it deserves closer scrutiny than it can receive in the paper. However, let me illustrate what I have in mind. To induce foreign investors to hold claims on developing countries in the form of marketable debt instruments, the recipient countries had to compensate investors for the potential risks involved. However, by qualifying to borrow in these markets, even if they should have been considered analogous to high-risk borrowers in domestic markets, borrowers in developing countries began to compete with a broader group of potential borrowers, not just other developing countries but issuers of bonds in developed countries as well. Moreover, the competition was based on judgments concerning the adequacy of the returns considering the risks involved -- evaluations that are relatively easy to make, at least in principle. But the comparisons are inherently multi-sided. Thus, when yields declined on the bonds issued by industrial countries, yields on instruments issued by developing countries became relatively more attractive. (Investors began to reach for higher yields, perhaps, as discussed above, not being as fully informed as they might have been about the risks involved.) similarly, wher. 
yields in industrial countries rose in 1994, those offered by developing countries such as Mexico became relatively less attractive. The issue is whether as a consequence of these structural changes, the borrowing countries become more vulnerable to external financial shocks.

B. Lessons from the Mexican Experience

The principal lesson from the Mexican experience in 1995 for recipients of capital inflows derives from the size, scope, and speed of the crisis once it broke. By the standards of the 1980s, this was a new world.

The earlier Mexican crisis took about six months to develop from the peso's devaluation in February 1982 to the Mexican weekend in mid-August. Once that crisis erupted, it was not until December that mechanisms were more or less fully in place to contain the situation. Meanwhile, about $\$ 3-1 / 2$ billion in bridge loans in August sufficed to buy time to put more permanent solutions in place, but it took three months before an agreement with the IMF was completed to form the other end of the bridge.

In 1994-95, the pre-crisis period lasted about a month, from mid-November to mid-December. An $\$ 18$ billion package of promised short-term financial assistance was developed within two (holiday) weeks, and by mid-January it was clear that the classical 1982 type of approach had failed to arrest the downward spiral of confidence. The U.S. Administration sought, and initially received, Congressional support for a $\$ 40$ billion program of guarantees for Mexican Government borrowings in 
international markets to refinance its short-term dollar and dollar-linked debt. That approach was abandoned on January 31 in favor of the approach now being followed. Thus, the crisis phase lasted a mere six weeks; it took another six weeks until midMarch before confidence began to return to Mexico. ${ }^{15}$ of course, there were many important differences between Mexico in 1982 and Mexico in 1995 that make comparisons somewhat problematic. However, there should be no doubt that the 1982 approach quickly proved to be inadequate in 1994-95, whether it deserved that fate or not.

A second lesson from the Mexican experience is merely a variation on a familiar, long-standing theme: If a country is going to run a large current account deficit financed by net private capital inflows, it needs to be careful to ensure that the funds are being wisely invested. This is the first principle for any type of borrowing. In the international context, it is relatively easy to articulate, but much more difficult to apply. However, it is clear in the Mexican case that its current account deficit was being driven in part by a decline in national savings from more than 18 percent of GDP in 1988-90 to less than 14 percent of GDP in 1994 and there was essentially no change in gross domestic investment. ${ }^{16}$ Thus, Mexico's domestic savings rate was relatively low, and when the Mexican economy increased its reliance on foreign savings very little of it went to

15. See the charts on stripped yields on Brady par bonds. 16. International Monetary Fund, World Economic Outlook, May 1995, page 92 . 
increased domestic investment. ${ }^{17}$

Three other obvious lessons of the Mexican experience deal with other aspects of governmental policy: First, countries should not be tempted to try to sustain overvalued exchange rates too long; this is another principle that is easy to articulate but not so easy to apply. Second, an easier lesson to apply is that in their debt management policies countries should avoid excessive reliance on short-term borrowing; since foreign as well as domestic investors buy internal as well as external Mexican debt, this lesson clearly applies to both areas of debt management. Third, when a country devalues or otherwise is forced to change its exchange-rate regime, there is a strong presumption that there should be compensating and complementary changes in other macroeconomic policies. In the Mexican case, this did not happen immediately either because the authorities were paralyzed by their governmental transition or they did not understand the fundamental issue. Supporting the "denial" interpretation is the fact that the Mexicans did not request IMF support until during the first week of January.

A final lesson from the Mexican experience I put forward more as a hypothesis than a firm conclusion. Has the changing nature of international capital flows left recipient countries more vulnerable to shocks? On the negative side, one can argue that countries can more easily attract capital flows and that

17. This is what the aggregate statistics show. Arguably, ith the increased flexibility and openness of the Mexican economy, the actual investments were more efficient and productive in the 1990s than earlier. 
they are now more open and can more easily do without the capital inflows and adjust to its loss with less (not zero, but less) pain -- in terms of lost output. On the affirmative side, it might appear that the unforgiving nature of capital markets implies that countries are more susceptible to severe punishment (in terms, again, of lost output) for marginal policy errors; on the other hand, increased market discipline contributes to more responsible policies. 18 As a practical matter, whether borrowing countries are more vulnerable to shocks today or not, they are less likely to receive much cooperation from their creditors in helping to cope with a crisis once it has erupted because individual creditors are more numerous and dispersed with less of a stake in the success of failure of efforts to resolve or contain a financial crisis.

\section{Implications}

Regardless of where one comes down on the issue of whether capital-importing developing countries are more vulnerable to shocks in today's globalized capital markets, one implication for the recipients of large scale of net capital inflows is that the authorities in these countries will need to pay a good deal more attention than they have in the recent past to potential shocks both external and internal. They will need to develop their own early warning systems. These systems should differ from and be independent of the early warning systems used

18. This is a lesson involving today's global financial ma kets that is far from unique to Mexico's situation. It is central to the evaluation of the ERM crises of 1992 and 1993 and the behavior of bond markets in 1994 . It is also subject to dispute. 
by investors or those used by official international financial organizations because the requirements and risks are inherently different.

One area to which particular attention needs to be paid in shock proofing the economies of the borrowing countries is the domestic banking system. Either because those banking systems lack the managerial or financial strength to exploit effectively liberalized financial markets, because national supervisory systems are underdeveloped, or because of the discipline that international capital flows exerts over macroeconomic policies (with consequent strains on the banking systems), such shock proofing is clearly needed. In the Mexican case, all three rationales were present. The newly privatized banks lacked strength and managerial experience, the effective tenor of their foreign currency liabilities was much less than that of their corresponding assets, the supervisory system was underdeveloped, and the weaknesses of the banking system contributed to the reluctance of the authorities to take the macroeconomic policy steps that would have been necessary to contain the peso crisis once it appeared that a devaluation was inevitable.

A second set of implications concerns macroeconomic policies in the recipient countries. Many advocates of the use of exchange rates as nominal anchors have been forced by recent events to retreat somewhat from their advocacy; it would be unfortunate if the pendulum now swung to the other extreme of 
absolutely freely floating exchange rates. ${ }^{19}$ The search for a workable, happy medium must continue.

At the same time, recipient countries will need to rethink how they calibrate their monetary policies, their debt management policies, and their fiscal policies. It follows from what I wrote above that I believe fiscal policy has a role to play in striking the proper balance between savings and investment, that is with respect to judging and achieving a sustainable current account balance, not only among recipients of net capital inflows among industrial countries like the United states but also for developing countries like Mexico. 20 In the face of unwanted capital inflows, which was Mexico's situation in 1992 and 1993, countries face difficult choices. Either fiscal policy should be tightened further even if it involves running a substantial fiscal surplus, or the real exchange rate must be allowed to appreciate, or capital inflows must be sterilized and reserves built up which often has negative fiscal consequences since interest receipts on external reserve holdings are less than interest payments on domestic obligations, or there should be resort to controls on capital inflows, or some combination.

19. Advocates of permanently fixed exchange rates and currency boards do not appear to have tempered their advocacy by much. 20. William Cline points out in his retrospective look at the debt crises of the 1980 s that the flaw in Nigel Lawson's dictum that current account deficits don't matter as long as they are accompanied by balanced budgets or surpluses applies equally to developing countries and developed countries, and he correctly diagnosed this flaw as applying to the Mexican case well b.-fare the crisis broke. William R. Cline. International Debt Reexamined, Institute for International Economics, Washington, DC, February 1995. 
The capital controls "solution" has attracted an increased amount of favorable attention in some quarters in the aftermath of the Mexican crisis. 21 However, I am skeptical about this latest turn in international monetary fashion. In many cases, it is only the countries with very sound macroeconomic policies and high domestic savings rates that can afford to limit capital inflows, and even they pay a price by distorting intertemporal decision making. Even when they do cut themselves off from some kinds of inflows (e.g., short-term borrowing), they are reluctant to cut themselves off from other kinds of flows (e.g., into stock markets or in the form of trade credits), and once the possibility of allowing some forms of short-term or portfolio capital inflows is opened up, the nature of any ensuing crisis is at most a matter of degree. Moreover, the notion that capital controls are a good idea for developing countries but a bad idea for developed countries runs counter to the truth that at the margin these two groups of countries cannot and should not be distinguished. 22

21. See, for example, the 1995 Annual Report of the Bank for International Settlements, "emerging economies should perhaps be...more prudent in dismantling controls on short term capital inflows," p. 210.

22. Larry Summers has expressed my bias with his characteristic zing, "it is clear that we would all rather live in countries in which capital is trying to get in, rather than in countries from which capital is trying to get out. That suggests that coun ries should be very cautious about imposing capital controls with the objective of discouraging capital inflows." Remarks at symposium on Capital Flows, Jerusalem, Israel, April 3, 1995. 


\section{The Functioning of the system}

\section{A. Recent Trends and Developments}

The principal change in the functioning of the international financial system in recent years has been the diminished role of governments. This trend is not only evident with respect to the process of privatization and market-opening reforms in the non-industrial world, it also has been manifested in the trend toward deregulation in the industrial world. The Ministry of Finance no longer has quite the unchallenged power and influence it once had in Japan, and financial markets have become increasingly deregulated in all industrial countries. 23

This trend toward deregulation has been driven by some of the same forces that are behind the globalization of financial markets and financial flows: technological change and improvements in global communications. It has facilitated the relative rise in the importance of securities markets and the relative decline in the role of depository institutions as direct financial intermediaries; that is, institutions that book both assets and liabilities on their balance sheets.

While there has been no observed trend toward increased volatility in those markets for financial assets that have been freely functioning for extended periods of time, for example, the market for U.S. Treasury securities and spot markets among the major currencies, recorded volatility has increased in markets

23. One does not need to go so far as to argue that central bankers are like the little Dutch boy with his finger in th. Jike against the onslaught of stateless money as steve solomon dues in his Confidence Game (Simon and Schuster, 1995) to recognize that the international financial system has changed. 
that previously were controlled. Where previously prices were tightly controlled with the result that sharp movements were ruled out or transactions were never consummated, now prices are allowed respond to shocks.

As noted above, the authorities have responded to these developments with a mixture of fear and awe. At one extreme they are concerned by the scale of potential disturbances, appearing to be handcuffed in their efforts to implement appropriate macroeconomic policies. At the other extreme, they have sought to exploit new opportunities including new ways of raising money. Could the Brady bond market have developed without the debt crisis of the 1980 s and without the financial technology available to support it? Without this market providing valuation benchmarks for trading in securities of developing countries, would it have been as easy for borrowers to price and come to market with other securities? These are difficult questions on which to reach firm conclusions. However, my answer to both questions is negative.

\section{B. Lessons from the Mexican Experience}

The principal lesson from the Mexican experience for the functioning of the international financial system is that the authorities have been required to rethink how they interact with the market in crisis situations. As noted earlier, gone are the days when the G-10 central banks could assemble a bridge loan in a few days that would serve to stabilize expectations about a major borrowing country's situation. Also gone are the days when the Managing Director of the IMF and the Chairman of the Boa,d of 
Governors of the Federal Reserve System could get representatives of 15 major private international financial institutions in a room and easily convince them that a systemic crisis is, first and foremost, a crisis for their own institutions. The number of major players is now much larger and each of them perceives that it has less of a stake in the successful resolution of a crisis situation. Thus, when the Mexican authorities in December 1994 called upon the commercial banks to assemble a line of credit to help Mexico cope with what appeared to be a liquidity crisis, the commercial bankers' principal focus was on the terms of the deal rather than on the rationale for the deal. Whether this was a short-sighted or mistaken judgement is open to debate.

A closely related lesson concerns the lack of consensus in the official community about the nature of the Mexican crisis and whether it involved so-called "systemic risk." From a broad perspective there were four possible elements of systemic risk in the Mexican situation.

First was the risk to banking systems in countries other than Mexico; this narrow definition of systemic risk focuses on depository institutions that are the core of monetary and payment systems and that have access to governmental safety nets for depository institutions. While bank claims on Mexico in early 1995 were a smaller share of Mexico's debt than in 1982, a fullblown Mexican crisis, which could have affected a number of other 
major borrowing countries, could have been a real threat to at least some national banking systems. ${ }^{24}$

Second was the risk to the international financial system more broadly defined covering not only depository institutions but other types of financial institutions and extending to stock and bond markets around the globe. I argued above that the loss of financial wealth as a consequence of contagion from the Mexican crisis was not likely to have been large enough by itself to have had a major impact on wealth, welfare or demand in the industrial countries, but adverse knockon financial or psychological effects could not be ruled out. Third was the risk to economic activity around the world, the possibility not only that the Mexican economy might go into a deep recession with negative spillover effects but also that the Mexican crisis might spread to other borrowers and impart a global deflationary impetus of considerable size. From the perspective of the end of December 1994, this risk was not seen as either very large or very troublesome coming off the euphoric growth performance in most of the industrial countries in 1994; from the perspective of mid-1995 against the background of slowing growth in many industrial countries (many with still very high unemployment rates) and deep fissures in the Japanese financial system, this risk might be evaluated differently. Finally there was the risk to the global trend toward market-oriented reforms that had swept the developing world over

24. Based on BIS data, which are not fully comparable for the two dates, bank claims on non-OPEC developing countries rose from $\$ 247$ billion in December 1982 to $\$ 489$ billion in December 1994 . 
the previous decade, drawing into the mainstream not only other countries in Latin America and the economics in transition in Eastern Europe and the area of the former Soviet Union but also countries such as China and India. If the authorities in Mexico, which, rightly or wrongly, was perceived to be a leader in this trend, concluded from their experience that they had chosen the wrong model and had reverted to a model emphasizing non-market solutions, so the argument went, then what would be the reaction in other formerly like-minded countries? Whether this is a relevant consideration under the heading of "systemic risk" is debatable, but that the authorities of most major borrowing countries sat down in January to consider the implications of the Mexican situation for their strategies is a fact. 25

My point is not primarily to argue that all these elements of systemic risk were present in the Mexican situation although I think they were, noting that risk means a non-zero probability. My point is that a lesson from the Mexican experience is that there was no consensus about the nature of the systemic risk involved, to say nothing of the size of that risk. Consequently, it is not surprising that there was a lack of consensus in the official community, as well as in private financial markets, about what to do about the problem. ${ }^{26}$

25. Again, see Krugman for a contrarian view: the Mexican peso crisis marked a healthy "beginning of the deflation of the Washington consensus," op. cit. p.31. 26 . This lack of consensus has been further exacerbated by the success of international efforts to stabilize Mexico's extej $7 \bar{i}$ financial situation. Some argue that it proves that the meaicine was necessary while others argue, incorrectly in my view, the reverse. 
A final lesson from the Mexican experience concerns the issue of transparency and markets. It is a lesson for the international financial system because transparency and the role of markets affect how the global financial system functions. In retrospect, it is clear that the Mexican authorities were less than fully forthcoming about their economic and financial situation; they were more transparent than critics in the market have argued, but they were not as transparent as they might have been. It was inappropriate that until early 1995 an important country like Mexico announced its international reserve position only three times a year or when it was otherwise convenient. It was an understandable anomaly that the Mexican authorities felt that it was in their interest to prevent the development of forward or futures market contracts in pesos. It was understandable because financial authorities are often behind the curve in such matters. It was an anomaly because it was inconsistent with other elements of market-oriented reform in Mexico. Some observers argue about the proper phasing of financial sector reforms in countries like Mexico and would like to slow down such reforms, but I would argue that in the Mexican case the absence of financial market facilities, such as a forward or futures market, to absorb pressures associated with the peso's devaluation was one, but only one, of the reasons why the peso crisis of 1994-95 was more virulent than the ERM crisis of 1992 . 
C. Implications

The first implication for the international financial system from the Mexican experience is that a better consensus needs to be established about the nature of systemic risks in these types of situations. That evaluation should take full account of the moral hazard implications of adopting too broad or explicit a definition. What were the stakes of the international financial system and the world economy as Mexico was forced to devalue the peso in December 1994? What were the potential systemic implications? The U.S. authorities did not see them the same way as did the authorities in some of the other major countries. 27

The second implication is that efforts to understand the functioning of financial markets and to safeguard their integrity should not be confined to markets in the industrial countries. This, again, is a respect in which the Mexican experience revealed that there is a continuum extending from the most sophisticated trading in foreign exchange markets involving the major currencies to domestic financial markets in developing countries. 28

Third is the implication for preventative activities. How best can the international financial community (private sector as well as public sector, including the international

27. This is not a clean distinction because disagreements about nature of the threat were mixed with disagreements about whose responsibility it was to meet any threat. 28. If the reader is not convinced by my assertion, conside ' the debate in early 1995 about how and why the dollar-mark and dollar-yen exchange rates may or may not have been affected by the Mexican peso crisis. 
financial institutions) organize itself in advance to increase the probability that Mexican-type situations either do not arise or do not involve such massive shocks either to the economy of the country directly involved or to the world economy and financial system? Among the elements of better prevention are increased transparency and provision of data to markets as well as the three types of early warning systems that were discussed in sections II--one each for the recipient country, the market participants, and the official international financial organizations.

Fourth, assuming that prevention is only 90 percent of any cure (at best), what should be the role of international rescue operations in such circumstances? Here there is the beginnings of a consensus in the statement that came out of the Halifax Summit. 29 While there is little objection to the principle that multilateral financial support should be

29. The Halifax Communique stated: If prevention fails, financial market distress requires that multilateral institutions and major economies be able to respond where appropriate in a quick and coordinated fashion. Financing mechanisms must operate on a scale and with the timeliness required to manage shocks effectively. In this context we urge the IMF to: establish a new standing procedure -"Emergency Financing Mechanism" - - which would provide faster access to Fund arrangements with strong conditionality and larger upfront disbursements in crisis situations.

To support this procedure, we ask:

the G-10 and other countries with the capacity to support the system to develop financing arrangements with the objective of doubling as soon as possible the amount currently available under the GAB [General Arrangements to Borrow] to respond to financial emergencies. 
potentially available to deal with certain crisis situations, there is considerable difference of view about how to define those crisis situations, whether it is realistic, in light of trends in international financial markets, to think that the multilateral institutions can mobilize enough financial resources to deal with the "next Mexico" or the "fifth Mexico" thereafter, and how to deal with these situations optimally (the moral hazard issue).

A final implication of the Mexican experience for the functioning of the international financial system is whether there is a better way to manage these crises? Such an examination realistically might proceed on the assumption that all crises will not, and perhaps should not, be preventable. The analysis might also assume that there will be a perceived need to try to manage a crisis so that it does minimal damage to the functioning of the international financial system and the world economy; in other words, the option of leaving the country to work out its problems with the market will not be attractive in all circumstances. Finally, the analysis might assume that sufficient external emergency resources may well not be available to handle all such situations. Put this way, the answer to the question of whether there should be a better way to handle these crises obviously is yes. An obvious answer to a complex question suggests the need to examine the stated assumptions. At the same time there is a need to examine the possible modalities of more orderly workout arrangements governing international debt crises than are currently available, for example, whether an offictally 
sanctioned standstill procedure that potentially would govern all external financial relations of a country in a crisis situation would be either feasible or desirable. ${ }^{30}$ It is premature to conclude what the results of such an examination should be, but it is not unreasonable to undertake it.

30. The Halifax Summit cautiously endorsed such an examination, "recognizing the complex legal and other issues posed in debt crisis situations by the wide variety of sources of internati racil finance involved, we would encourage further review by G-10 Ministers and Governors of other procedures that might also usefully be considered for their orderly resolution." 


\section{International Finance Discussion Papers}

IFDP

Number

535

534 Currency Crashes in Emerging Markets: An Empirical Treatment

533 Regional Patterns in the Law of One Price: The Roles of Geography vs. Currencies

\section{5}

532 Aggregate Productivity and the Productivity of Aggregates

531 A Century of Trade Elasticities for Canada, Japan, and the United States

$530 \quad$ Modelling Inflation in Australia

529 Hyperinflation and Stabilisation: Cagan Revisited

$528 \quad$ On the Inverse of the Covariance Matrix in Portfolio Analysis

527 International Comparisons of the Levels of Unit Labor Costs in Manufacturing

526 Uncertainty, Instrument Choice, and the Uniqueness of Nash Equilibrium: Microeconomic and Macroeconomic Examples

525 Targeting Inflation in the 1990s: Recent Challenges

524 Economic Development and Intergenerational Economic Mobility

523 Human Capital Accumulation, Fertility and Growth: A Re-Analysis
Author(s)

Edwin M. Truman

Jeffrey A. Frankel

Andrew K. Rose

Charles Engel

John H. Rogers

Susanto Basu

John G. Fernald

Jaime Marquez

Gordon de Brouwer

Neil R. Ericsson

Marcus Miller

Lei Zhang

Guy V.G. Stevens

Peter Hooper

Elizabeth Vrankovich

Dale W. Henderson

Ning S. Zhu

Richard T. Freeman

Jonathan L. Willis

Murat F. Iyigun

Murat F. Iyigun

Please address requests for copies to International Finance Discussion Papers, Division of International Finance, Stop 24, Board of Governors of the Federal Reserve System,

Washington, D.C. 20551 . 


\section{International Finance Discussion Papers}

IFDP

Number

519

516

\author{
Titles
}

1995

Excess Returns and Risk at the Long End of the Treasury Market: An EGARCH-M Approach

The Money Transmission Mechanism in Mexico

When is Monetary Policy Effective?

Central Bank Independence, Inflation and Growth in Transition Economies

Alternative Approaches to Real Exchange Rates and Real Interest Rates: Three Up and Three Down

Product market competition and the impact of price uncertainty on investment: some evidence from U.S. manufacturing industries

Block Distributed Methods for Solving

Multi-country Econometric Models

Supply-side sources of inflation: evidence from OECD countries

Capital Flight from the Countries in Transition:

Some Theory and Empirical Evidence

Bank Lending and Economic Activity in Japan:

Did "Financial Factors" Contribute to the Recent

Downturn?

Evidence on Nominal Wage Rigidity From a Panel of U.S. Manufacturing Industries

Do Taxes Matter for Long-Run Growth?: Harberger's Superneutrality Conjecture

Options, Sunspots, and the Creation of Uncertainty
Allan D. Brunner

David P. Simon

Martina Copelman Alejandro M. Werner

John Ammer

Allan D. Brunner

Prakash Loungani

Nathan Sheets

Hali J. Edison

William R. Melick

Vivek Ghosal

Prakash Loungani

Jon Faust

Ralph Tryon

Prakash Loungani

Phillip Swagel

Nathan Sheets

Allan D. Brunner

Steven B. Kamin

Vivek Ghosal

Prakash Loungani

Enrique G. Mendoza

Gian Maria Milesi-Ferretti

Patrick Asea

David Bowman

Jon Faust 


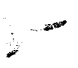

